introduced before the convulsions become too marked, it recovers. But when the pressure of oxygen is gradually raised above the normal, the animal again dies of convulsions. This is evidently not the effect of mere increase in atmospheric pressure, but the effect of the oxygen on the animal, inasmuch as 25 atmospheres of com non air are required to produce the oxygen convulsions, while 3 atmospheres of pure oxygen are sufficient. This effect is readily explained on the hypothesis of interference by supposing that the absence of oxygen retards the transmission of impulse; in the nerve-centres; so that we get those which ou ght ordinarily to inhibit one another, coinciding and causing convulsions. Increased supply of oxygen gradually quickens the transmission of impulses until the waves first reach the normal relation, and then the normal rate being exceeded, the impulses once more nearly coincide, and convulsions are produced a second time.

In discussing the action of the nervous system we have hitherto taken into azcount only that of the nerve fibrils, and left out of the question the nerve cells. We have assumed that the waves arrived in the reservoir (in our diagram) from a distance, and were simply transmitted along channels, but in the nervous system we have to take into account the origination of the waves in the nerve cells themselves, as well as their propagation along the nerve channels.

There is a great difference between the function of the nerve cell and of the nerve fibre analogous to that which exists between the cell and the wire in a galvanic battery. The particular form of energy which we met with in both cases originates in the cell and is transmitted along the fibre or the wire. In both cases also the energy appears to originate from chemical changes going on in the cell. Material waste of some sort goes on in both, and in both the products of this waste if allowed to accu nulate will by and by arrest the action.

We find an indication of the difference between the amount of chemical change which goes on in the nerve cell and in the nerve fibre in the amount of blood sup. plied to each respectively. The nerve cells are abundantly supplied with blood, and tha nerve fibres very sparingly so. The free supply of blood secures to the nerve cells both the supply of fresh material and ready removal of waste products.

Perhaps the best illustration that we can find in physics of the processes which take place in the nervous and muscular systems is however afforded by singing flame; in which the sound; and movements are produced by very numerous small explosions : for both in the nervous and muscular systems the tissue change appears to go on as a series of small explosions. The material which yields nervous and muscular energy undergoes oxidation, but the oxygen concerned in the process is not derived directly from the external air. Substances which yield oxygen are contained within the tissues themselves just as nitre is contained along with oxidisable substances in a charge of gunpowder.

In this paper also we have spoken of waves of nervous interference as if they were simple, but it is much more probable that they are very complex, resembling much more the beats of sound produced by two singing flames which are not in unison, than simple waves of water.

The number of nervous discharges which issue from the motor cells of the spinal cord during tetanus and set the muscles in action is, according to Dr. Burdon Sanderson, about 16 per second, but in all probability each of these impulses consists of a large number of small vibrations. In rhythmical actions, such as that of the respiration, we have probably at the very least three rhythms, Ist, exceedingly rapid vibrations in the nervous cells; 2nd, slower vibrations or beats from 16 or 18 per second, which issue from them and excite the muscles to action; and 3 rd, a still slower rhythm, of 16 per minute, probably due to interference between groups of cells, which leads to inspiratory movements alternating with rest or with active exspiration. The consideration of these complicated phenomena would, however, at present lead us tos far, and they as well as the subject of nervous interference in the heart and rhythmic contraction of muscles, must be reserved for another time.

In this paper I must be content with the attempt to show that inhibition and stimulation in the nervous system are not dependent on special inhibitory or stimulating centres, but are merely relative conditions depending on the length of path along which the stimulus has to travel and the rate of its transmission. The test of the truth or falsehood of this hypothesis is to be found in the effect of alteration in the rapidity of nervous transmission upon inhibitory phenomena. The application of this test appears, so far as our present data go, to support this hypothesis.

T. LAUDER BRUNTON

\section{BEN NEVIS OBSERVATORY}

I N NATURE, vol. xxvii. p. 39, I gave a brief notice that on November I-owing to stress of weather forbidding the regular daily ascents of Ben Nevis - I was obliged to discontinue the daily work of the meteorological observing system on the summit and slopes of the mountain. This was in simultaneous connection with my system of observations near the sea-level at Arhintore, Fort William. As in the previous summer, I had the honour to organise and carry on the work under the auspices of the Scottish Meteorological Society. The experience gained in $188 \mathrm{r}$, when I first commenced observins on the Ben, enabled me to draw up and submit to the Society a more elaborate plan of mountain observation for the summer and autumn of 1882 ; and as I have been fortunate enough to carry it through for five months without any hitch, and as I am not aware that anything of the kind had, previous to my first undertaking, been attempted, I am naturally anxious that NATURE should have a more complete account of my last year's operations. My plan was to have fixed stations at different altitudes between the main observatories at the base and on the summit of the mountain so plazed in fact that I could observe regularly at halfhourly intervals during the daily ascent and descent of the Ben; to extend the number of summit observations to five sets; and to have in every case simultaneous observations taken at the sea-level station-my grand base of operations. All this was with a view to localising disturbances existing in the stratum of atmosphere between the sea-level and the top of Ben Nevis, to furthering meteorological research generally, and so ultimately to gain forecasting material. I arrived at Fort William from Edinburgh on May 25, and at once proceeded to give effect to my plans. During the next few days I was engaged mainly in erecting Stevenson's thermometer screens, and laying out the sea-level station; in establishing a new "midway" observatory at the lake, erecting screen, and building there a granite cairn for a barometer and in reopening the temporary observatory on the summit of the mountain. It was only by dint of great exertion and a gang of men that I got all in order on the top of the Ben on May 3I. I had no occasion, however, to alter the arrangements of the previous summer; and the heavy work of reopening chiefly consisted in digging out from the vast accumulations of snow the barometer cairn, hut, and thermometer cage which here, as a safeguard, incloses Stevenson's screen. The snow, in fact, was nearly four feet deep, and it was necessary to cut out wide areas around the instruments. I also erected another screen to contain Negretti and Zambra's self-registering clock-hygrometer, most kindly placed at my disposal by that eminent firm for the purpose of obtaining 9 p.m. values. I had also to fix a new roof of ship's canvas to the rude shanty that affords some little 
shelter from the piercing cold and storms. The barometer, a fine Fortin, had been left in its cairn built up during the past winter; and great labour was expended before the north side of the cairn was reopened, the stones being so hard frozen that a crowbar had to be employed. The instrument was found in good condition.

Passing over all other details of arranging the stations and fixing instruments, I may say that I had all in order and commenced work on June I. I now give a list of the stations, with positions, hours, and elements of observation. ${ }^{1}$ The distances in the text are given in right lines from the sea-level station. Fig. I at once shows the bearings, and distances by the actual track followed.
Fig. 2 is a longitudinal section giving total actual distances.

ACHINTORE, FORT WILliam, BASE OR SEA-LEVEL OBSERVATORY.--Yosition: About 28 feet above sea, on a level sward, perfectly open on all sides, running parallel and imme diately adjacent to Loch Linnhe; soil, gravelly loam.

Hours. - 5, 5.30, 6.15, 7, 7.30, 7.55; 8.30, 9, 9.30, 10, I0.30, II, and II.30 a.m. ; and noon, 0.30, I, I.45, 2.30, 3, 6, and 9 p.m.

Elements.-Atmospheric pressure by mercurial barometer, temperature of air and evaporation (dry and wet bulbs), direction and force of wind, kind and amount of
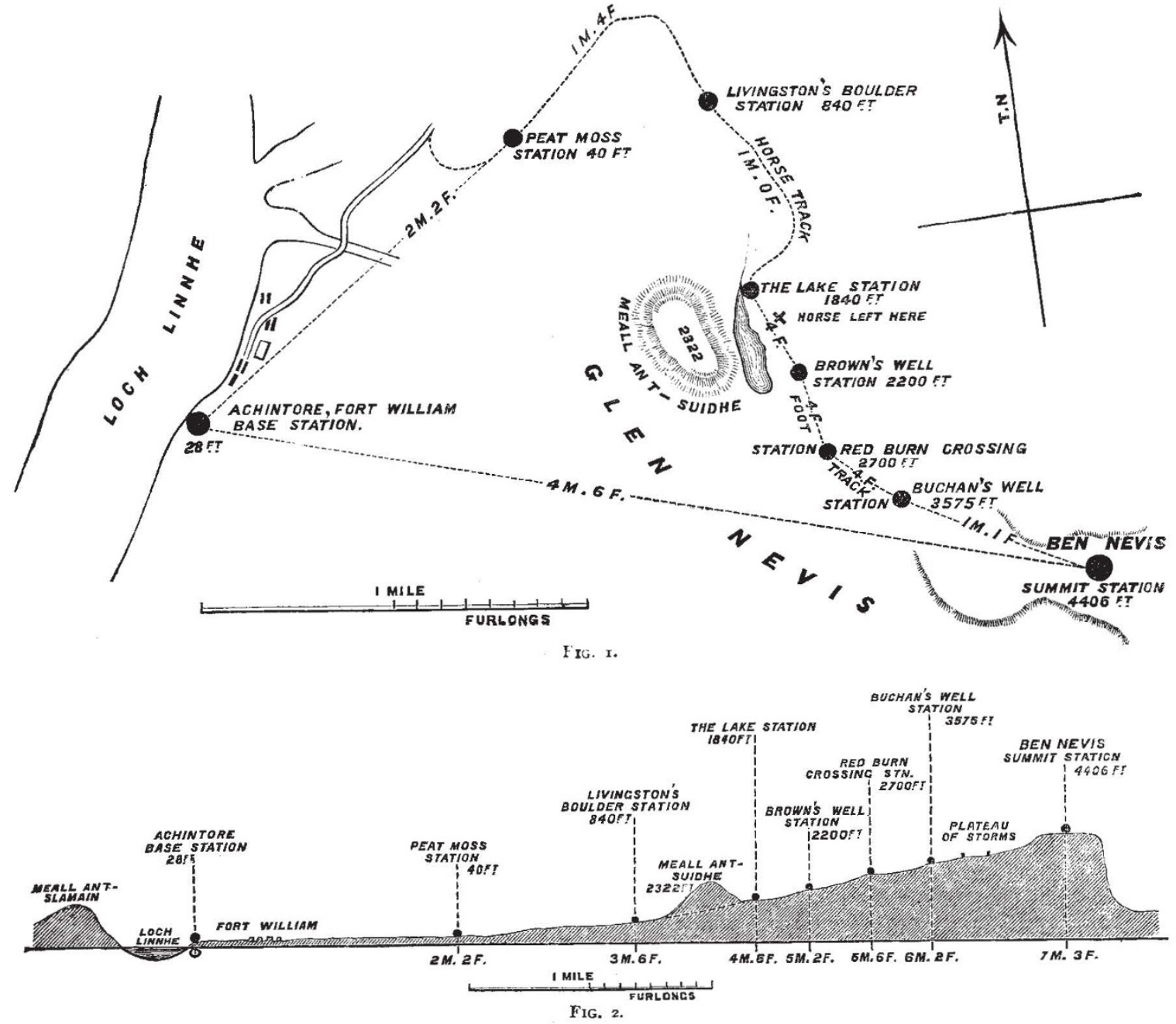

cloud, and movements and velocities of the various strata of cloud, hydrometeors and remarks in full detail at all the above times. Maximum and minimum shade temperature, solar maximum and terrestrial minimum tem. perature, earth temperature ( $\mathrm{I}$ and 2 feet), and rainfall at 9 a.m. and 9 p.m. Temperature of Achintore well, and subsequently of Loch Linnhe between 9 and II a.m.

Ozone for periods of $\frac{1}{2}$ hour, I hour, $I \frac{1}{2}$ hour, and 2 hours between 9 and II a.m.; also for periods of 24 and 12 hours, ending 9 a.m. and 9 p.m. Czone also for the following periods of exposure -6 hours ending 1 p.m., and 18 hours ending 7 a.m., and subsequently in addition for 15 hours ending 5.30 a.m., and 9 hours ending

${ }^{x}$ Cloud movements and velocities $\mathrm{x}$ re no ${ }^{+}$, however, noted at solutely every time.

2.30 p.m. [It will be seen later that all these ozone observations (except those for 12 hours ending 9 o'clock) were simultaneous with others on the summit of Ben Nevis, at the Lake, and Peat Moss stations.]

Actinism of the sun's rays and of daylight by Dr. Angus Smith's apparatus for 24 hours ending 10.17 a.m. ; comparison-pressure by aneroid at 5 a.m. and 3 p.m. on leaving for and returning from the summit and slopes' stations.

PEAT Moss.-Position: Atout 40 feet above sea; $2 \mathrm{~m}$. $2 \mathrm{f}$. ; perfectly open; near the middle of the extensive moss at the foot of Meall an $t$-Suidhe; peaty, swampy soil, with hummocks around.

Hours. -5.30 to 6 a.m. (this was the only hour in the entire system that varied, and extra simultaneous read- 
ings were taken at Achintore whenever this was the case), and 2.30 p.m. From August I also at 9, 9.30, I0, 10.30, and I I a.m.

Elements.-Temperature of air and evaporation (dry and wet bulbs), wind and force; kind of cloud, amount and velocity; hydrometeors and remarks in full detail as before at all the above times. Pressure by aneroid, 5.30 to 6 a.m., and at 2.30 p.m. Rainfall at 9 a.m. Ozone for 15 hours, ending about 5.30 a.m., and for about 9 hours, ending $2.30 \mathrm{p.m}$.; also for periods of $\frac{1}{2}$ hour, I hour, I $\frac{1}{2}$ hour, and 2 hours between 9 and 11 a.m. (simultaneously with the summit and base stations). Temperature of adjacent water-hole subsequently about $5.30 \mathrm{a} . \mathrm{m}$. and 2.30 p.m.

PEAT MOSS CROSSING,-A minor station about 70 feet above sea, 3m. of., situated at the burn Allt Coire an Lochain.

Hours and Elements.-About 5.50 a.m. and 2.17 p.m. : pressure by aneroid, and temperature of burn.

Livingston's Boulder. ${ }^{1}$ - Position: 840 feet above sea ; 3m. If. ; close to the burn Allt Coire an Lochain, on a level swampy patch; ground around undulating, with large boulders of coarse-grained granite lying adjacent.

Hours. -6. I 5 a.m. and r. 45 p.m.

Elements.-Pressure by aneroid, temperature of air and evaporation (dry and wet bulbs), temperature of burn; wind and force; kind of cloud, amount and velocity; hydrometeors and remarks in full detail as before each time.

THE LAKE.-Position: A plateau-valley I840 feet above

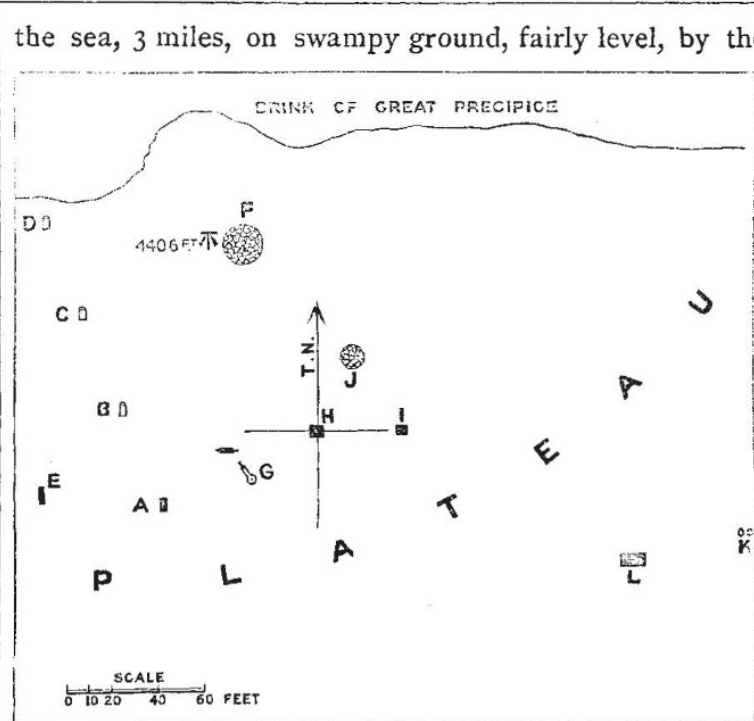

FIG. 3. -A, B, C, D, raingauges; $E$, notice board; $F$, Ordnance Survey cairn; $G$, solar and terrestrial radiation thermometers; $H$, Stevenson's thermometer cage and ozone tests; I, self-registering hygrometer; $I$, barometer cairn; K, earth thermometers ; 1 , hut. The apparatus for actinism of light is near the edge of the precipice N.E. from the hut.

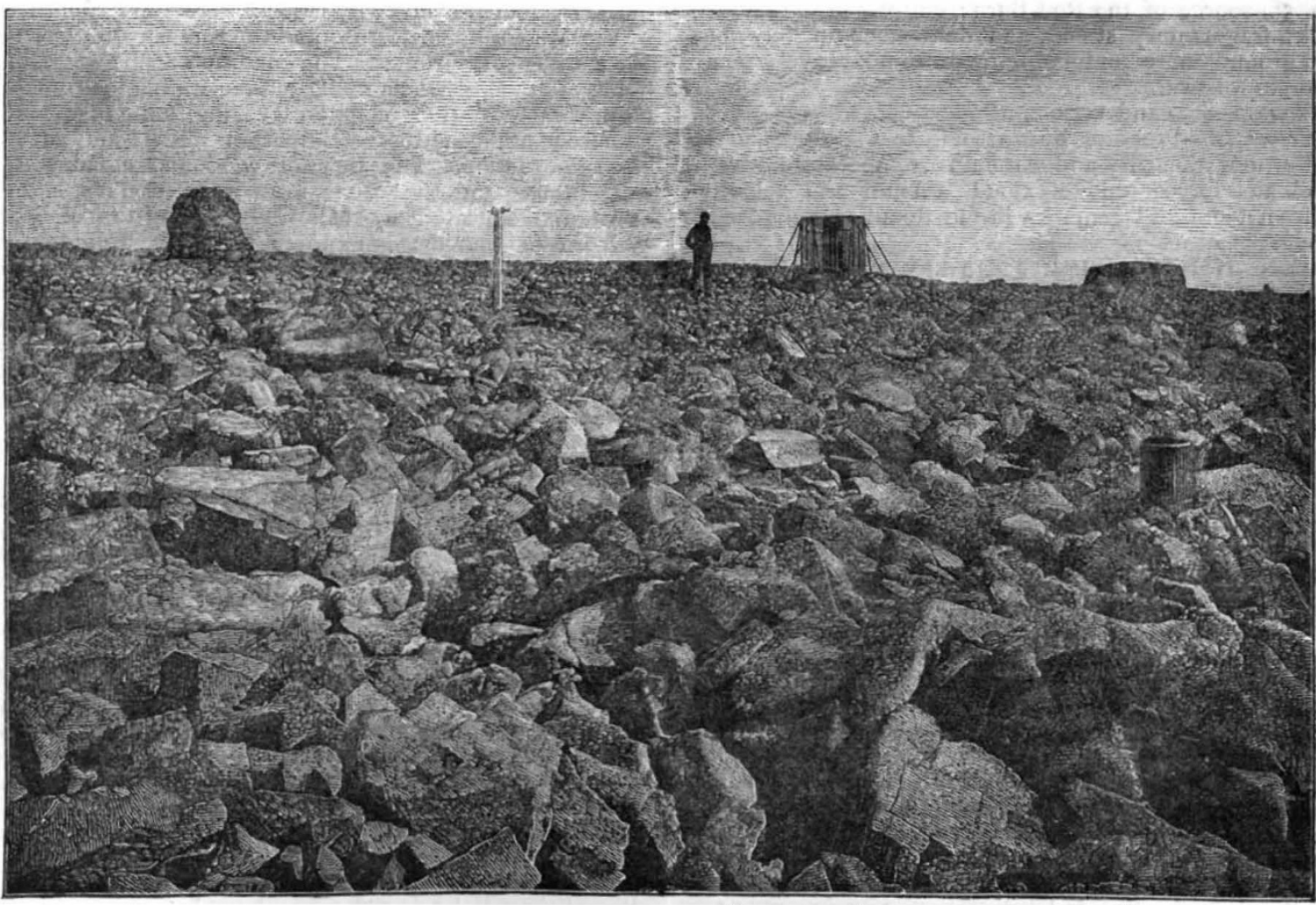

Barometer Cairn.

Solar Radiation Thermometer.

Thermometer Cage. FIG. 4. granite blocks and hummocks of bog, moss, and dwarf-

1 The altitude of this station and those of the following intermediate stations, except the Lake, were determined by mean results of aneroid readings, and must be accepted accordingly. heather to eastward. Main slopes of Ben Nevis on eastsouth-east side, and Meall an $t$-Suidhe on west side.

Hours. $\rightarrow$ a.m. and I p.m.

Elements.-Pressure by mercurial barometer, com- 
parison-pressure by aneroid, temperature of air and evaporation (dry an $₫$ wet bulos), maximum and minimum shade temperature, and ozone for periods of 6 and 18 hours, temperature of ground at depths of I and 2 feet; temperature of lake; wind and force; kind of cloud, a nount and velocity; hydrometeors and remarks in full detail as bafore each time. Rzinfall on 1 st, 8 th, $15^{\text {th }}$, and 22 nd oc each month.

BRown's Well.-Position: 2200 feet above sea, $3 \mathrm{~m}$. If., on a grassy patsh with springs and swamps, on the main slopes of Ben Nevis. Boulders and stones of finegrained granite graduating into felsite lie around. Slope to westward estimated at $35^{\circ}$.

Hours. $\rightarrow 7.30$ a.m. and 0.30 p.m.

Elements. - Pressure by aneroid, temperature of air and evaporation (dry and wet bulbs), temperature of well; wind and force; kind of cloud, amount and velocity; hydrometeors and remarks in full detail as before each time.

RED BURn CRossing.-Position: 2700 feet above sea, $3 \mathrm{~m}$. $2 \mathrm{f}$., above the general limit of vegetation in the deep ravine of and close beside the Red Burn; boulder; and debris of porphyritic rock on all sides; slope to westward estimated at $40^{\circ}$.

Hours. -7.55 a.m. and noon.

Elements.-Pressure by aneroid, temperature of air and evaporation (dry and wet bulbs), temperature of burn; wind and force; kind of cloud, amount and velocity; hydrometeors and remarks in full detail as before each time.

Buchan's Well. - Position: 3575 feet above sea, $3 \mathrm{~m}$. 5 f., source of the Red Burn: entirely in a region of rocks, fragmentary stones, and debris; completely open, and ground more undulating, with comparatively gentle slope to westward.

Hours. -8.30 and I I.30 a.m.

Elements.-Pressure by aneroid, temperature of air and evaporation (dry and wet bulbs), temperature of well; wind and force; kind of cloud, amount and velocity; hydromsteors and remark; in full detail as before each time.

BEN NEVIS, SUMMIT OBservatory.-Position : 4405 feet above sea, $4 \mathrm{~m}$. $6 \mathrm{f}$, in the centre of a rough ro:ky plateau, covered with felstone lavas and volcanic ag slomerates (see Figs. 3 and 4).

Hours. $-9,9.30$, 10, 10.30, and i 1 a.m.

Elements.--Pressure by mercurial barometer, comparison-pressure by aneroid, temperature of air and evaporation (dry and wet bulbs), wind and force ; kind of cloud, amount, and velocities of strata; hydrometeors and remarks in fullest detail as at the sea-level and intermediate stations at all the above times.

Maximum and minimun shade temperature, solar maximum and terrestrial minimum temperature, and rainfall by four gauges at 9 a.m.

Temperature of Wragge's Well and of ground at depths of $I$ and 2 feet between 9 and $1 \mathrm{I}$ a.m.

Ozone for periods of $\frac{1}{2}$ hour, I hour, I $\frac{1}{2}$ hour, and 2 hours between 9 and II a.m., also by two differently exposed tests for 24 hours ending 9 a.m.

Actinism of the sun's rays and of daylight by Dr. Angus Smith's apparatus for 24 hours ending 10.17 a.m.

Hygrometric conditions prevailing about 9 o'closk the previous night by self-registering dry and wet bulbs, were noted at 10.50 a.m.

A moment's consideration, then, will show that the observations at the sea-level station were in every case simultaneous with those at the summit and intermediate stations, and that the hours at the latter were so arranged as to "mean" to the Io a.m. readings at the base and summit of the mountain, and also at the Peat Moss.

Rainband by Browning's spectroscope was observed at various altitudes, and its indications proved of considerable value. Full notes were taken of the cloud limits, and of any important changes observed between the stations.

OF course my first business was to get the main observations-pressure, temperature, hygrometric conditions, wind, cloud, \&c.- -into full swing by June 1 ; and as I felt my way and got my hours and distances well under command I added to my work. Thus the ozone observing-system and the three extra rain-gauges on the summit were added on June 15 , and the delicate operations for measuring the actinism of light on July 9. The additional gauges were established to discover if and to what extent the rainfall varies in connection with the wind at different points of the plateau from the centre to the edge of the great precipice.

During June, Stevenson's screens were in use only at the sea-level, lake, and summit; and hence at the other places the dry and wet bulbs had to be swung and the latter moistened afresh from adjacent water at each swinging. But aching wrists and sore fingers soon made me determine to have louvred screens at all the stations, and by July $\mathrm{I}$ they were in their plazes and dry and wet -bulbs supplied by Hicks and Negretti and Zambra fixed permanently in each. So above all was accuracy the better insured, and the whole system went like clockwork. I left Achintore before 5.30 a.m., and returned about 3 p.m., and the rate of ascending and descending was so regulated as to insure punctuality usually within a few seconds-often to the second-at th $\geqslant$ various stations.

The new screens were a trifle smaller than the others. I nee 1 hardly add that the instruments at all stations were the best observing-standards procurable, and that the arrangements in every respect were those approved by the Meteorological Office and the English and Scottish Meterrological Sorieties. The condition of the wet bulbs, fixing of ozone tests, clamping self-registering instruments to prevent vibration in gales, levelling rain-gauges, and numerous other matters of important decail required the closest attention. The Beaufort wind and cloud scales were in use, and the ozone tests were Moffat's. Two assistants, educated by Mr. Colin Livingston of Fort William -a sufficient guarantee for their ability-and trained by myself, helped in the work; and relieved me in the ascent of the mountain three times a week, and on these occasions I too' $z$ the sex-level station. One of the greatest difficulties I hat to contend with in the Ben Nevis routine was as to the pony on which I rote to and fro.n the Lake, where it was left to graze and await my descent. Occasionally the stable-boy overslept, and I had to make up for lost time, - no easy matter, as the wretched track lead; over deep rut; and treacherous swamps, and the poor brute had a trying time of it. Still more frequently the person to whom it belonged gave me rotten saddlery in spite of all remonstrance; and on commencing the ascent the girth would break, and I had to turn the animal a lrift and plod on to the Lake my fastest. This was decidedly hard, inasmuch as I was obliged to climb afoot some 2500 feet fro $n$ the tarn in less than two hours by a circuitous route and over rough rock slopping to observe at the other intermediate stations. Again, the pony often wandered in his hobbles or having broken the tethering rope had made off to the moss; so also on the homeward journey I had sometimes to leave him and run my hardest over ruts and through swamps, by a short cut, to get my readings at the next station. Other trying part; of the work consisted in the journeys between Buchan's Well and the top in the allotted time, in having the two hours' exposure on the summit in bad weather, and in becoming chilled after profuse perspiration. The rule hut, with its walls full of holes of all shapes and angles through which the wind whistles and the snow-drifts drive, afforded but a poor shelter from the dren shing rain and cold, and it was im. possible to keep anything dry. My hands often became so numbed and swollen, and my paper so saturated that I had 
the utmost difficulty in handling keys, setting instruments and entering my observations. Usually so laden was the air with moisture and so very dense and lasting was the cloud-fog that, even when no rain had actually fallen, all the fixings and instruments were dripping; and although, of course, I made a point of wiping the dry bulb, it almost immediately became wet again. Occasionally I timed the interval between wiping and fresh condensation on the bulb, and have found it wet again within thirty seconds.

After November I, then, I had to discontinue the work. The hut had become choked with snow, and the carrying on of the undertaking satisfactorily impossible. I was, however, satisfied; and very pleased that I had secured five months' observations without the break of a single day.

It is not my part to refer in this paper to any results. Such I must in duty leave to be discussed and made known by the Scottish Meteorological Society. But, from what I myself know of the meteorology of Ben Nevis from the experience of two summers and autumns, I do most strongly urge the establisbment of a permanent observatory on the summit, firmly believing that most important and unexpected results will accrue to meteorology from continuous observations there. Such, in connection with others at the sea-level, would in my opinion enable the energetic staff at the Meteorological Office, under Mr. Robert H. Scott's able direction, to forecast storms with far greater certainty.

I cannot conclude this account without expressing my best acknowledgments to Dr. Angus Smith for placing at my disposal his apparatus for measuring the actinism of light, which I consider an immense acquisition to a meteorological observatory; to Mr. John Browning for his rainband spectroscope; to Messrs. Negretti and Zambra for their clock-hygrometer; and finally to the Scottish Meteorological Society for the kind encouragement and liberal assistance they have given me.

\section{Clement Lindley Wragge}

\section{HYDROGEN WHISTLES}

T may be recollected by some of the readers of NATURE that a few years ago ${ }^{1}$ I contrived a whistle for testing the upper limits of the power of hearing very shrill notes by different men and animals. When properly made, it easily suffices to do this, in the case of men and most animals, but it cannot, neither can any other instrument hitherto devised, emit such notes as it is conceivable that insects may hear. The problem whether any insects can hear notes whose numbers of vibrations per second is manyfold greater than those of the notes audible to men bas not yet been fairly put to the test of experiment. wish to show that this can now be done.

The whistles of which I speak have their lower ends closed with a piston that admits of being inserted more or less deeply, and thus of varying the depth of the whistle and consequently its note; but as a whistle will not give its proper note unless its depth be greater than its width, say, I $\frac{1}{2}$ times as mucb, and as the depth of a whistle that gives, say, 24,0co vibrations per second is is only $0^{\circ} 4$ inch, it follows that their bores must be very small, and that a limit of minuteness is soon reached.

Having had occasion lately to reconsider the subject, it occurred to me that I cculd greatly increase the shrillness of any whistle by blowing a gas through it that was lighter than common air.

The number of vibrations per second caused by whistles is inversely proportional to the specific gravity of the gas that is blown through them; therefore by the use of bydrogen, which is thirteen times lighter than air, the

I "South Kensington Conferences, in "connection with Loan Exhibition of Scientific Apparatus, 1876," p. 6x. number of vibrations per second produced by a given whistle would be increased thirteenfold.

I have made experiments with most satisfactory results with common coal gas, whose specific gravity, though much greater than that of hydrogen, is not much more than half that of common air, and I have little doubt in consequence that a number of vibrations may be excited by one of my small-bore whistles through the use of hydrogen gas, that very largely exceeds the number attainable hitherto in any other way. They would of course fail to excite the sense of sound in any of ourselves, or perhaps to produce any physical effect that we can appreciate, whether on sensitive flames or otherwise, and the note to those creatures, if any, who could hear it, would be feebler on account of the lightness of the medium in which the vibrations originated, but it would be (so far as I can anticipate) a true note, and ought to be powerful enough to be audible at the short distances at which small creatures may be tested. The whistle I used was made for me by Hawksley, 357, Oxford Street ; its bore is $0^{\circ} \mathrm{O} 4$ inch diameter, and it gives a loud note for its size. After some prefatory trials, I proceeded as follows:-I attached the whistle to a gas jet by a short indiarubber tube. Then, without turning on the gas, I retested my range of hearing by setting the piston at various lengths and giving sharp squeezes to the tube as it lay in the hollow of my hand. The effect of each squeeze was to force a little air through the whistle, and to cause it to emit a sharp "cheep." When I relaxed the grasp, air was sucked in through the whistle, and the tube became again filled with air, ready for another squeeze.

My range of hearing proved to be such that when the depth of the whistle was 0.13 inch, I could hear no musical note at all-only a puff ; at $0^{\prime} 14$ inch I could just perceive a very faint musical note enveloped, as it were, in much puff; even at 0.20 some little puff remained, but before $0^{\circ} 25$ the note had become purely musical. This having been established, I kept the whistle set at 0.25 and turned the gas on, giving it abundance of time to expel all air from the tube. Then, turning the stopcock to shut the indiarubber tube from behind, I gave a sharp squeeze as previously, but the whistle, instead of emitting a pure note, gave to me just the same barely perceptible sound that it did when it was set at $0^{\circ}$ I4. I relaxed my grasp and instantly retightened it, and then the whistle emitted a pure note. A little common air had regurgitated into the whistle when my grasp was relaxed, and it was the reissue of this that gave the note. I repeated the experiment several times with the same result. With a depth of 0.24 I could hear no note at all when using the gas. Then I pulled out the piston to $0^{\circ} 35$, and the gas gave a clear musical note; on the second squeeze the note was considerably deepened. The specific gravity of the gas from the jet, as calculated from these data, would be to that of the air at the time, as 14 to 25 , or as 0.56 to $\mathrm{I}$. This happens to be the specific gravity of carburetted hydrogen, but that of common street gas is heavier. Perhaps my measurements were not quite accurate; probably the note given by the gas being really fainter (though not perceptibly so) than that given by air somewhat falsified the judgment. A very slight difference in the data would raise the 0.56 to 0.60 or more.

By the use of hydrogen the little whistle when set at $0^{\prime}$ I 4 inches would produce 312,000 vibrations per second. I know by experiment on others that it will give a true musical note when made much shorter than this, and I see no cause to doubt that it will sound truly at half the above length, and therefore be capable of emitting twice the atove enormous number of vibrations per second.

Mr. Hawksley is making for me an apparatus with small gas bag for hydrogen pure or diluted, valves, and an indiarubber ball to squeeze, to enable hydrogen to be used with the whistle when desired. The whistle is 